\title{
BEHAVIOR IN SPORTS ACTIVITY AMIDST PANDEMIC OF STUDENT-ATHLETES OF LYCEUM OF THE PHILIPPINES UNIVERSITY, CAVITE
}

\author{
Renato S. Tanglao Jr. \\ Graduate School, Laguna State Polytechnic University, Santa Cruz, Laguna, Philippines
}

Article DOI: https://doi.org/10.36713/epra7461 DOI No: 10.36713/epra7461

\begin{abstract}
This study determined the behavior in sports activity of student-athletes of Lyceum of the Philippines University, Cavite. Specifically, the study sought answers to the following questions: What is the status of profile of studentathletes of the Lyceum of the Philippines University, Cavite in terms of; age; sex; gender; sports event? What is the level of behavior of students-athlete in terms of: physical activity; emotional Behavior; social activity; psychological? What is the level of sports activity in terms of: training; coaching; tune up games; competition? Is the demographic profile of the student athletes has a significant effect in the sports activity? Is the behavior of the student has a significant effect in the sports activity?

In order to conduct this study, letters was sent to Ms. Kimberly Joy E.

Alcaraz OIC Head, Research and Publications Office and the University Headmaster, Mr. Mhar Angelo A. Bayot asking permission and approval to conduct the study.

Permission from the OIC Head, Research and Publications Office and university headmaster for each department. Preparation of self-made questionnaire by the researcher followed in order to obtain the necessary data on the behavior in sports activity amidst pandemic of student-athletes of Lyceum of the Philippines University, Cavite. The respondents of the study included approximately fifty (50) student-athletes of different event enrolled in the Lyceum of the Philippines University, Cavite. The copies were multiples and others sent by the google form considering the health protocols. The main source of data which prepared by the researcher were statistically use a simple descriptive statistic such as T-test formula and the weighted mean to determine the mean level to know the behavior in sports activity amidst pandemic of student-athletes of Lyceum of the Philippines, Cavite. readiness of the student-athletes to the new normal sports competition participated by the Cavite.
\end{abstract}

\section{INTRODUCTION}

As most sports seasons, practices and camps have been canceled in all area due to the coronavirus pandemic, many athletes, including high school and college seniors, may be experiencing a sense of loss and resentment. Psychological science faces a call to action researching the implications of the corona virus disease 2019 (COVID-19) pandemic. Rapid reviews have reported that maintaining rigorous research standards is a priority for the field, such as ensuring reliable and valid measurement, when investigating peoples experience of COVID-19, O’Connor et al., (2020).

This pandemic has caused many events in our environment around the world. And one of the most severely affected are athletes who experience different emotions caused by stopping regular training and competition. All ages for different reasons, high school kids are impacted in a multitude of ways; they are undergoing hormonal changes and use sports as a way to help reduce stress and control anxiety and depression. Also, sports are a way to earn college scholarships so there can be increased pressure. 


\section{SJIF Impact Factor 2021: 8.013| ISI I.F.Value:1.241| Journal DOI: 10.36713/epra2016 ISSN: 2455-7838(Online) EPRA International Journal of Research and Development (IJRD) Volume: 6 | Issue: 7 | July 2021 \\ - Peer Reviewed Journal}

Much of this work highlights a link between the athlete environment and experiences of depression and anxiety. For example, serious injury causing early retirement and loss of identity, organizational-level pressures and occupational demands, public scrutiny of performance and person, have all been linked with mental health disorders (Foskett and Longstaff, 2018).

For younger children, sports are often a way to socialize and build upon those skills. When school and other social interactions have been taken away, not having sports can cause a child to feel isolated. Definitely see sports changing, but how they change is hard to predict. We can look at other countries and see how they are beginning to roll sports back out. Most likely games will be played without fans on a professional level to start. Then when fans do return, they will most likely require wearing a mask and other social distancing measures. Players on the bench will most likely be six feet apart as well. Sports may opt not to do any handshakes or high fives as well. That is, measurement assumptions are critical for the field moving forward ensuring confidence in findings which may inform policy, and training.

Through this, the aim of this research was to analyze the behavior in sports activity amidst pandemic of student-athletes of Lyceum of the Philippines University, Cavite.

\section{OBJECTIVES}

This study determined the behavior in sports activity amidst pandemic of student-athletes of Lyceum of the Philippines University, Cavite. Specifically, the study sought answers to the following questions:

1. What is the STATUS OF PROFILE of student-athletes of the Lyceum of the Philippines University, Cavite IN terms of;

1.1 Age;

$1.2 \mathrm{Sex}$;

1.3 Gender;

1.4 Sports Event?

2. What is the level of behavior of students-athlete in terms of:
2.1 Physical activity;
2.2 Emotional Behavior;
2.3 Social Activity;
2.4Psychological?

3. What is the level of sports activity in terms of :
3.1 Training;
3.2 Coaching;
3.3 Tune up games;
3.4 Competition?

4. Is the demographic profile of the student athletes has a significant effect in the sports activity?

5. Is the behavior of the student has a significant effect in the sports activity?

\section{METHODOLOGY}

The researcher consulted her statistician on the sampling techniques. Purposive sampling, also known as judgmental, selective, or subjective sampling, is a form of non-probability sampling in which researcher rely on their own judgment when choosing members of the population to participate in their study. This sampling method requires researchers to have prior knowledge about the purpose of their studies so that they can properly choose and approach eligible participants. Researchers use purposive sampling when they want to access a particular subset of people, as all participants of a study are selected because they fit a particular profile. Each individual was chosen entirely by chance and each member of the population has an equal chance of being included in the sample. The respondents of the study included approximately fifty (50) student-athletes of different event enrolled in the Lyceum of the Philippines University, Cavite 


\section{SJIF Impact Factor 2021: 8.013| ISI I.F.Value:1.241| Journal DOI: 10.36713/epra2016 ISSN: 2455-7838(Online) EPRA International Journal of Research and Development (IJRD) Volume: 6 | Issue: 7 | July 2021

In order to conduct this study, letters was sent to the University Headmaster, Mr. Mhar Angelo A. Bayot asking permission and approval to conduct the study.

Permission from the university headmaster for each department. Preparation of self-made questionnaire by the researcher followed in order to obtain the necessary data on the behavior in sports activity amidst pandemic of student-athletes of Lyceum of the Philippines University, Cavite.

The researcher-made questionnaire was checked by the thesis adviser. Face validation of the contents of the questionnaire was done by the adviser of the researcher and other panel members in the researchers list. They are vital panel members of the research department.

The copies of the questionnaire was multiplied based from the number of the respondents. Then it was administered. With confidentiality, the gathered information was transferred in a tally sheet. Subsequently, codes was assigned to each indicator. The encoded data was given to the researcher's statistician for the descriptive analysis. The gathered data was interpreted and presented in textual and tabular forms and appropriate interpretation was made.

The following statistical tools were used in order to analyze and interpret the gathered data:

Descriptive statistics will be going to apply to properly derive information and frequency distributions of the gathered data.

The respondents will be identified using the Slovin's formula: $\mathrm{n}$ (sample size) $=\mathrm{N}$ (population) $/ 1+\mathrm{N}$ (population) $\mathrm{x} \mathrm{e}^{2}$ (margin of error at 0.05 squared). The answers of the respondents on the evaluation about the conducting study behavior in sports activity amidst pandemic of student-athletes of Lyceum of the Philippines University, Cavite is going to be analyze using the following formulas and measurements:

Weighted mean - used to find out the average responses of the respondents as measurement of the central tendency.

T-Test Formula - The formula for the two-sample t-test (a.k.a. the Student's t-test) is shown below. In this formula, $\mathrm{t}$ is the $\mathrm{t}$-value, $\mathrm{x}_{1}$ and $\mathrm{x}_{2}$ are the means of the two groups being compared, $\mathrm{s}_{2}$ is the pooled standard error of the two groups, and $\mathrm{n}_{1}$ and $\mathrm{n}_{2}$ are the number of observations in each of the groups. T-test is used to know if there is a behavior in sports activity amidst pandemic of student-athletes of Lyceum of the Philippines University, Cavite significant effect to the sports activity and behavior of the student-athletes of the Lyceum of the Philippines University, Cavite.

\section{RESULT AND DISCUSSION}

This chapter deals with the presentation, analysis and interpretation of data gathered to answer the sub problem relative to the main problem of this study on behavior in sports activity of amidst pandemic of studentathletes. This part discusses the findings of the study based on the research questions.

\section{DEMOGRAPHIC PROFILE OF THE STUDENT-ATHELETES}

Figure 2 shows the status of the student-athletes of the Lyceum of the Philippines University, Cavite in terms of Age. 


\section{Age}

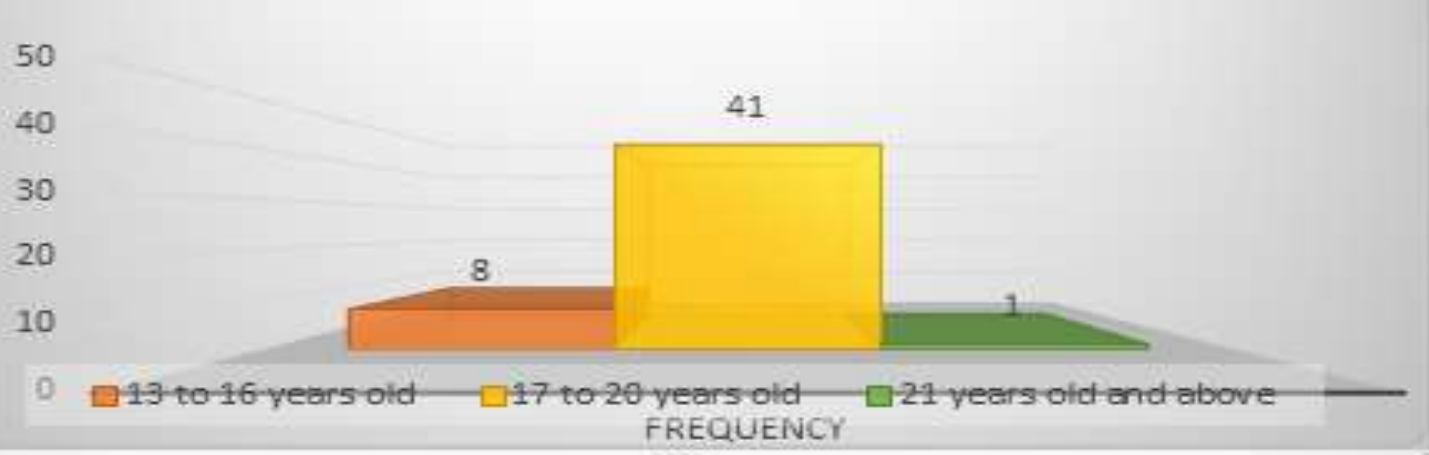

Graph shows that ages "17 to 20 years old" have the highest frequency of forty-one (41) or $82.00 \%$ of the total respondent. And have eight (8) or $16.00 \%$ of the respondent are "13 to 16 years old". While the ages " 21 years old and above" received the lowest frequency of one (1) or $2.00 \%$ of the total respondents

Figure 3 below shows the status of the student athletes of the Lyceum of the Philippines University Cavite in terms of Sex.

Graph shows that sex "Male" has the highest frequency of forty-three (43) or $86.00 \%$ of the total respondent. While the sex "Female" received the lowest frequency of seven (7) or $14.00 \%$ of the total respondents.

Figure 4 Status of profile of the student-athletes of the Lyceum of the Philippines University, Cavite in terms of Gender. 


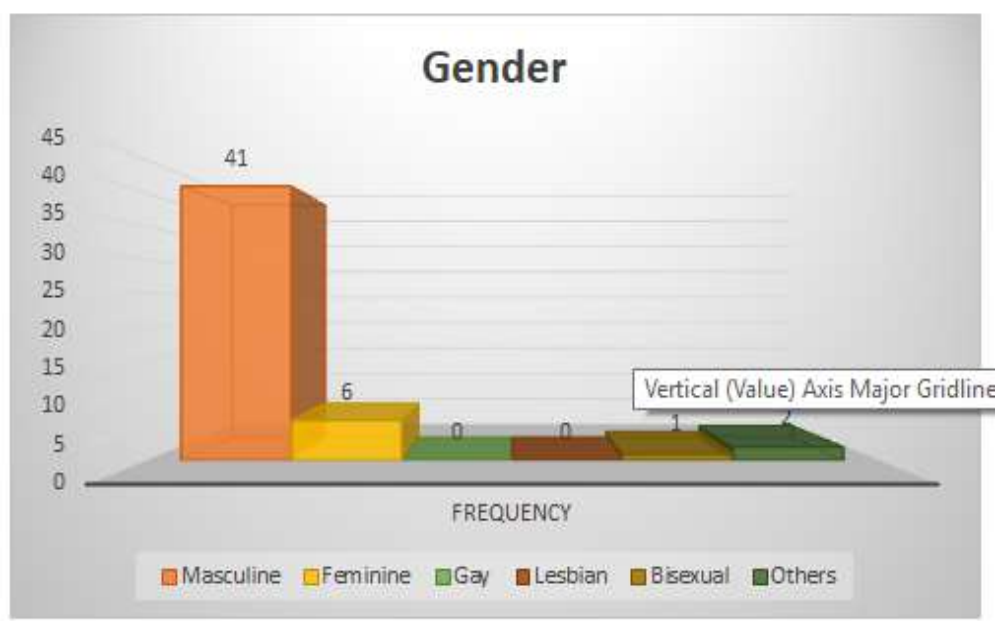

Graph shows that gender "Masculine" has the highest frequency of forty-one (41) or $82.00 \%$ of the total respondent. And have six (6) or $12.00 \%$ of the respondent are "Feminine". While the gender "Bisexual" received the lowest frequency of one (1) or $2.00 \%$ of the total respondents.

Figure 5 Demographic profile of student-athlete of the Lyceum of the Philippines University, Cavite in terms of sports events.

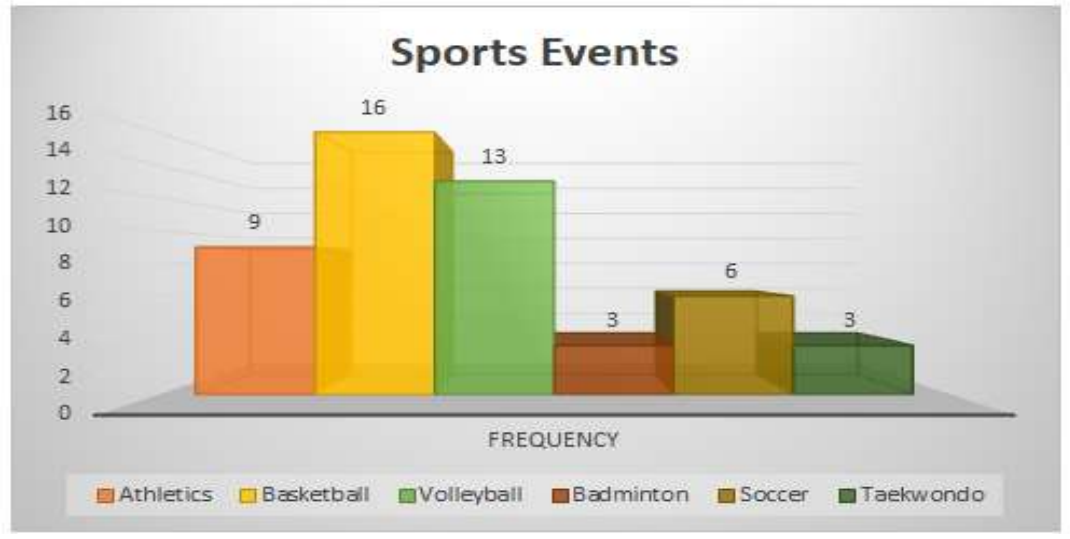

Graph shows that the event "Basketball" has the highest frequency of sixteen (16) or 32.00\% of the total respondent. And have thirteen (13) or $26.00 \%$ of the respondent are in "Volleyball". While the event "Badminton and Taekwondo" received the lowest frequency of three (3) or $6.00 \%$ of the total respondents

Table 1. Level of the behavior of the student-athlete in terms of Physical activity

\begin{tabular}{|l|l|l|l|}
\hline \multicolumn{1}{|c|}{ Statements } & Mean & SD & Remarks \\
\hline 1. Go for a 30 mins walk at least three times a week. & 4.58 & 0.54 & Always \\
\hline 2. I do biking as part of exercise. & 4.48 & 0.61 & Always \\
\hline 3. I walk to grocery stores in an immediate time. & 4.62 & 0.49 & Always \\
\hline 4. I walk to school for an important matter. & 4.56 & 0.50 & Always \\
\hline 5. I do house works as an exercise & 4.70 & 0.46 & Always \\
\hline $\begin{array}{l}\text { Overall Mean }=\mathbf{4 . 5 9} \\
\text { Standard Deviation }=\mathbf{0 . 5 2 5} \\
\text { Verbal Interpretation }=\text { Very High }\end{array}$ & & \\
\end{tabular}




\section{SJIF Impact Factor 2021: 8.013| ISI I.F.Value:1.241| Journal DOI: 10.36713/epra2016 ISSN: 2455-7838(Online) EPRA International Journal of Research and Development (IJRD)

Table 1 shows the result on level of the behavior of the student-athlete in terms of Physical activity. Based on the respondents' perceptions, the level of the behavior of the student-athlete in terms of Physical activity was generally very high. They do house works as an exercise have $(M=4.70, S D=0.46)$ and walk to grocery stores in an immediate time with $(M=4.62, S D=0.49)$. They do bike as part of exercise with $(M=4.48, S D=0.61)$; and this item got the lowest rating. All item indicators got a verbal interpretation of very high, as disclosed by the overall mean of 4.59 and supported with standard deviation value of 0.525 .

Table 2. Level of the behavior of the student-athlete in terms of Emotional behavior

\begin{tabular}{|l|l|l|l|}
\hline \multicolumn{1}{|c|}{ Statements } & Mean & SD & Remarks \\
\hline $\begin{array}{l}\text { 1. I secure my future by means of pursuing their education } \\
\text { amidst pandemic. }\end{array}$ & 4.58 & 0.50 & Always \\
\hline $\begin{array}{l}\text { 2. I consider the advice of the LGU to stay at home in the } \\
\text { announcement of ECQ. }\end{array}$ & 4.52 & 0.50 & Always \\
\hline 3. I monitor the health status of family members. & 4.56 & 0.50 & Always \\
\hline 4. I'Il find time to do the meditation for relaxation & 4.52 & 0.50 & Always \\
\hline $\begin{array}{l}\text { 5. I talk to a trusted friend to express the feeling of being } \\
\text { hurt, happy and lonely. }\end{array}$ & 4.56 & 0.50 & Always \\
\hline $\begin{array}{l}\text { Overall Mean }=\mathbf{4 . 5 5} \\
\text { Standard Deviation }=\mathbf{0 . 4 9 9} \\
\text { Verbal Interpretation }=\text { Very High }\end{array}$ & & & \\
\hline
\end{tabular}

Table 2 shows the level of the student behavior in terms of behavior. Based on the respondents' perceptions, the level of the behavior of the student-athlete in terms of Emotional behavior was generally very high They secure future by means of pursuing their education amidst pandemic have $(M=4.58, S D=0.50)$ and monitor the health status of family members and talk to a trusted friend to express the feeling of being hurt, happy and lonely with $(M=4.56, S D=0.50)$. They consider the advice of the $L G U$ to stay at home in the announcement of ECQ and find time to do the meditation for relaxation with $(M=4.52, S D=0.50)$; and this item got the lowest rating. All item indicators got a verbal interpretation of very high, as disclosed by the overall mean of 4.55 and supported with standard deviation value of 0.499 .

Table 3. Level of the behavior of the student-athlete in terms of Social activity.

\begin{tabular}{|l|c|c|c|}
\hline \multicolumn{1}{|c|}{ Statements } & Mean & SD & Remarks \\
\hline $\begin{array}{l}\text { l.I meet friends for some small talk practicing the social } \\
\text { distancing. }\end{array}$ & 4.70 & 0.50 & Always \\
\hline $\begin{array}{l}\text { 2. I eat outside like picnics in observance of physical } \\
\text { distancing. }\end{array}$ & 4.66 & 0.50 & Always \\
\hline 3. I play outside in my sports discipline with friends. & 4.74 & 0.40 & Always \\
\hline $\begin{array}{l}\text { 4. I attend occasions with precautionary measures and } \\
\text { protocols observance. }\end{array}$ & 4.68 & 0.50 & Always \\
\hline $\begin{array}{l}\text { 5. I do the group work assigned by the teachers with } \\
\text { classmates. }\end{array}$ & 4.68 & 0.50 & Always \\
\hline $\begin{array}{l}\text { Overall Mean } \mathbf{= 4 . 6 9} \\
\text { Standard Deviation }=\mathbf{0 . 4 6 3} \\
\text { Verbal Interpretation }=\text { Very High }\end{array}$ & & & \\
\hline
\end{tabular}

Table 3 shows the level of the behavior of the student-athlete in terms of social activity. Based on the respondents' perceptions, the level of the behavior of the student-athlete in terms of Social activity was generally very high. They play outside in sports discipline with friends have $(M=4.74, S D=0.40)$ and meet friends for some small talk practicing the social distancing with $(M=4.70, S D=0.50)$. They eat outside like picnics in observance of physical distancing with $(M=4.66, S D=0.50)$; and this item got the lowest rating. All item indicators got a verbal interpretation of very high, as disclosed by the overall mean of 4.69 and supported with standard deviation value of 0.463 . 
Table 4. Level of the behavior of the student-athlete in terms of Psychological aspect

\begin{tabular}{|l|l|l|l|}
\hline \multicolumn{1}{|c|}{ Statements } & Mean & SD & Remarks \\
\hline 1. I think the best way to relive the feeling of insecurity. & 4.74 & 0.40 & Always \\
\hline 2. I stay strong in times of trials. & 4.72 & 0.50 & Always \\
\hline 3. I find solution for the certain problems encountered. & 4.74 & 0.40 & Always \\
\hline $\begin{array}{l}\text { 4. I fight the feeling of anxiety and depression by means of } \\
\text { doing things that could relax me. }\end{array}$ & 4.78 & 0.40 & Always \\
\hline 5. I go to a place that I could appreciate the value of life. & 4.76 & 0.43 & Always \\
\hline $\begin{array}{l}\text { Overall Mean }=\mathbf{4 . 7 5} \\
\text { Standard Deviation }=\mathbf{0 . 4 3 5} \\
\text { Verbal Interpretation }=\text { Very High }\end{array}$ & & \\
\hline
\end{tabular}

Table 4 show the data of the level of the behavior of the student-athlete in terms of Psychological aspect. Based on the respondents' perceptions, the level of the behavior of the student-athlete in terms of Psychological aspect was generally very high. They fight the feeling of anxiety and depression by means of doing things that could relax have $(M=4.78, S D=0.40)$ and go to a place that I could appreciate the value of life with $(M=4.76, S D=0.43)$. They stay strong in times of trials with $(M=4.72, S D=0.50)$; and this item got the lowest rating. All item indicators got a verbal interpretation of very high, as disclosed by the overall mean of 4.75 and supported with standard deviation value of 0.435 .

Table 5. Level of sports activity in terms of Training

\begin{tabular}{|l|c|c|c|}
\hline \multicolumn{1}{|c|}{ Statements } & Mean & SD & Remarks \\
\hline $\begin{array}{l}\text { 1. I check the body temperature with the use of thermometer } \\
\text { before the training. }\end{array}$ & 4.78 & 0.40 & Always \\
\hline $\begin{array}{l}\text { 2. I do the cardio exercise such as running/ jogging to } \\
\text { maintain the endurance. }\end{array}$ & 4.72 & 0.50 & Always \\
\hline $\begin{array}{l}\text { 3. I do the strengthening exercise, or resistance training, } \\
\text { such as push ups and using the dumbbells. }\end{array}$ & 4.78 & 0.40 & Always \\
\hline $\begin{array}{l}\text { 4. I use the agility test for the measurement and maintenance } \\
\text { of the workouts. }\end{array}$ & 4.70 & 0.50 & Always \\
\hline $\begin{array}{l}\text { 5. I do regular training in my specific sports discipline in } \\
\text { preparation for the new normal competition. }\end{array}$ & 4.68 & 0.47 & Always \\
\hline $\begin{array}{l}\text { Overall Mean }=\mathbf{4 . 7 3} \\
\text { Standard Deviation }=\mathbf{0 . 4 4 4} \\
\text { Verbal Interpretation }=\text { Very High }\end{array}$ & & \\
\hline
\end{tabular}

Table 5 shows the result of the Level of sports activity in terms of Training. Based on the respondents' perceptions, the level of sports activity in terms of Training was generally very high. They check the body temperature with the use of thermometer before the training and do the strengthening exercise, or resistance training, such as push ups and using the dumbbells have $(M=4.78, S D=0.40)$ and do the cardio exercise such as running/ jogging to maintain the endurance with $(M=4.72, S D=0.50)$. They do regular training in my specific sports discipline in preparation for the new normal competition with $(M=4.68, S D=0.47)$; and this item got the lowest rating. All item indicators got a verbal interpretation of very high, as disclosed by the overall mean of 4.73 and supported with standard deviation value of 0.444 . 
Table 6. Level of sports activity in terms of Coaching

\begin{tabular}{|l|c|c|c|}
\hline \multicolumn{1}{|c|}{ Statements } & Mean & SD & Remarks \\
\hline $\begin{array}{l}\text { 1. I am democratic to all teammates that gives the team } \\
\text { freedom and accountability, with the coach stepping in } \\
\text { only when needed to keep the process going }\end{array}$ & 4.72 & 0.50 & Always \\
\hline $\begin{array}{l}\text { 2. I talk to each other and decide what to do and when and } \\
\text { how to do it. }\end{array}$ & 4.72 & 0.50 & Always \\
\hline $\begin{array}{l}\text { 3. I teach life skills in hopes towards developing positive } \\
\text { relationships with each other. }\end{array}$ & 4.76 & 0.40 & Always \\
\hline $\begin{array}{l}\text { 4. I know how to tap into the individual strength to get the } \\
\text { most out of them }\end{array}$ & 4.74 & 0.40 & Always \\
\hline $\begin{array}{l}\text { 5. I get the greatest amount of productivity from the team, } \\
\text { collectively and individually. }\end{array}$ & 4.68 & 0.47 & Always \\
\hline $\begin{array}{l}\text { Overall Mean }=\mathbf{4 . 7 2} \\
\text { Standard Deviation }=\mathbf{0 . 4 4 8} \\
\text { Verbal Interpretation }=\mathbf{V} \text { Very High }\end{array}$ & & & \\
\hline
\end{tabular}

Table 6 Level of sports activity in terms of Coaching. Based on the respondents' perceptions, the level of sports activity in terms of Coaching was generally very high. They teach life skills in hopes towards developing positive relationships with each other have $(M=4.76, S D=0.40)$ and know how to tap into the individual strength to get the most out of them with $(M=4.78, S D=0.40)$. They get the greatest amount of productivity from the team, collectively and individually with $(M=4.68, S D=0.47)$; and this item got the lowest rating. All item indicators got a verbal interpretation of very high, as disclosed by the overall mean of 4.72 and supported with standard deviation value of 0.448 .

Table 7. Level of sports activity in terms of Tune up games

\begin{tabular}{|l|c|c|c|}
\hline \multicolumn{1}{|c|}{ Statements } & Mean & SD & Remarks \\
\hline $\begin{array}{l}\text { I. I get familiarized with the surroundings and the } \\
\text { competition venue. }\end{array}$ & 4.76 & 0.40 & Always \\
\hline $\begin{array}{l}\text { 2. I set the mind and goals for clear and well performance } \\
\text { for the friendly game competition. }\end{array}$ & 4.72 & 0.50 & Always \\
\hline $\begin{array}{l}\text { 3. I build confidence and increase chance of positive } \\
\text { performance outcome. }\end{array}$ & 4.68 & 0.50 & Always \\
\hline 4. I stay focused and optimistic. & 4.72 & 0.50 & Always \\
\hline $\begin{array}{l}\text { 5. I prepare meal plan and follow religiously the coach } \\
\text { advise for the win. }\end{array}$ & 4.68 & 0.47 & Always \\
\hline $\begin{array}{l}\text { Overall Mean }=\mathbf{4 . 7 1} \\
\text { Standard Deviation }=\mathbf{0 . 4 5 4} \\
\text { Verbal Interpretation }=\text { Very High }\end{array}$ & & & \\
\hline
\end{tabular}

Table 7 shows the data of the level of sports activity in terms of Tune up games. Based on the respondents' perceptions, the level of sports activity in terms of Tune up games was generally very high. They get familiarized with the surroundings and the competition venue have $(M=4.76, S D=0.40)$ and set the mind and goals for clear and well performance for the friendly game competition and stay focused and optimistic with $(M=4.72, S D=0.50)$. They build confidence and increase chance of positive performance outcome and prepare meal plan and follow religiously the coach advise for the win with $(M=4.68, S D=0.50,0.47)$; and this item got the lowest rating. All item indicators got a verbal interpretation of very high, as disclosed by the overall mean of 4.71 and supported with standard deviation value of 0.454 . 
Table 8. Level of sports activity in terms of Competition

\begin{tabular}{|l|l|l|l|}
\hline \multicolumn{1}{|c|}{ Statements } & Mean & SD & Remarks \\
\hline 1. I relax and pray before the competition. & 4.76 & 0.40 & Always \\
\hline 2. I visualize winning the game. & 4.74 & 0.40 & Always \\
\hline 3. I get enough sleep to boost energy and stay healthy. & 4.72 & 0.50 & Always \\
\hline 4. I know the rules, give my best and apply what I trained. & 4.80 & 0.40 & Always \\
\hline $\begin{array}{l}\text { 5. I instill sportsmanship, and do the right thing before, } \\
\text { during and after the game. }\end{array}$ & 4.82 & 0.39 & Always \\
\hline $\begin{array}{l}\text { Overall Mean }=\mathbf{4 . 7 7} \\
\text { Standard Deviation }=\mathbf{0 . 4 2 3} \\
\text { Verbal Interpretation }=\text { Very High }\end{array}$ & & \\
\hline
\end{tabular}

Table 8 shows the data results of the level of sports activity in terms of Competition. Based on the respondents' perceptions, the level of sports activity in terms of Competition was generally very high. They instill sportsmanship, and do the right thing before, during and after the game have $(M=4.82, S D=0.39)$ and $k n o w$ the rules, give the best and apply what they trained with $(M=4.80, S D=0.40)$. They get enough sleep to boost energy and stay healthy with $(M=4.72, S D=0.50)$; and this item got the lowest rating. All item indicators got a verbal interpretation of very high, as disclosed by the overall mean of 4.77 and supported with standard deviation value of 0.423 .

Table 9. Significant effect of the demographic profile of the student-athlete to the sports activity

\begin{tabular}{|c|c|c|c|c|}
\hline Age & Beta & $\mathrm{t}$-value & $\mathrm{p}$-value & Analysis \\
\hline Training & 0.051 & 0.043 & 0.966 & Not Significant \\
\hline Coaching & -0.95 & -0.554 & 0.582 & Not Significant \\
\hline Tune up games & 0.885 & 0.486 & 0.629 & Not Significant \\
\hline Competition & -0.282 & -0.333 & 0.740 & Not Significant \\
\hline \multicolumn{5}{|l|}{ Sex } \\
\hline Training & 0.344 & 0.581 & 0.564 & Not Significant \\
\hline Coaching & -1.596 & -1.798 & 0.079 & Not Significant \\
\hline Tune up games & 2.554 & 2.837 & 0.007 & Significant \\
\hline Competition & -2.056 & -4.910 & 0.000 & Significant \\
\hline \multicolumn{5}{|l|}{ Gender } \\
\hline Training & 0.982 & 0.405 & 0.688 & Not Significant \\
\hline Coaching & -4.561 & -1.253 & 0.217 & Not Significant \\
\hline Tune up games & 7.296 & 1.976 & 0.054 & Not Significant \\
\hline Competition & -5.873 & -3.421 & 0.001 & Significant \\
\hline \multicolumn{5}{|l|}{ Sports Events } \\
\hline Training & 0.482 & 0.235 & 0.815 & Not Significant \\
\hline Coaching & -5.167 & -1.680 & 0.099 & Significant \\
\hline Tune up games & 5.531 & 1.774 & 0.083 & Not Significant \\
\hline Competition & -4.155 & -2.866 & 0.006 & Significant \\
\hline \multicolumn{5}{|c|}{ Adjusted R-Square: 0.7284} \\
\hline $\begin{array}{l}\text { F-value: } \\
\text { ig.: }\end{array}$ & & & & \\
\hline
\end{tabular}

Table 9 shows the significant effect of the demographic profile of the student-athlete to the sports activity. Results from Table 9 revealed that the Sports Activity had no effect on demographic profile of the student-athlete. The beta coefficient indicates that for every standard deviation unit increase in Training, Coaching, tune up games and Competition, there is a corresponding unit increase in the demographic profile of the student-athlete. The t-value of Training, Coaching, tune up games and Competition is not significant having a p-value of greater than 0.05 level of significance. 
This means that the demographic profile of the student-athlete to the sports activity was not influenced by age, gender, sex and sports events.Based on the data, it is shown that there is "no significant effect of the demographic profile of the student-athlete to the sports activity" at 0.05 level of significance. It shows that the null hypothesis stating that "There is no significant effect of the demographic profile of the student-athlete to the sports activity" is accepted, it can inferred that there is "no significant" effect between them.

Table 10. Significant effect of the behavior of the student in the sports activity

\begin{tabular}{|c|c|c|c|c|}
\hline Physical & Beta & t-value & p-value & Analysis \\
\hline Training & 0.133 & 0.189 & 0.851 & Not Significant \\
\hline Coaching & 2.522 & 2.386 & 0.021 & Significant \\
\hline Tune up games & -1.773 & -1.654 & 0.105 & Not Significant \\
\hline Competition & 0.081 & 0.162 & 0.872 & Not Significant \\
\hline \multicolumn{5}{|l|}{ Emotional } \\
\hline Training & 0.171 & 0.976 & 0.334 & Not Significant \\
\hline Coaching & 1.704 & 6.474 & 0.000 & Significant \\
\hline Tune up games & -0.728 & -2.727 & 0.009 & Significant \\
\hline Competition & -0.159 & -1.288 & 0.204 & Not Significant \\
\hline \multicolumn{5}{|l|}{ Social } \\
\hline Training & -0.007 & -0.007 & 0.995 & Not Significant \\
\hline Coaching & 2.627 & 1.775 & 0.083 & Not Significant \\
\hline Tune up games & -1.780 & -1.186 & 0.242 & Not Significant \\
\hline Competition & -0.039 & -0.056 & 0.956 & Not Significant \\
\hline \multicolumn{5}{|l|}{ Psychological } \\
\hline Training & 0.427 & 6.273 & 0.000 & Significant \\
\hline Coaching & -1.280 & -12.53 & 0.000 & Significant \\
\hline Tune up games & 1.703 & 16.448 & 0.000 & Significant \\
\hline Competition & 0.153 & 3.176 & 0.003 & Significant \\
\hline
\end{tabular}

Table 10 shows the significant effect of the behavior of the student in the sports activity. Results from Table 10 revealed that the Sports Activity had no effect on behavior of the student-athlete. The beta coefficient indicates that for every standard deviation unit increase in Training, Coaching, Tune up games and Competition, there is a corresponding unit increase in the behavior of the student-athlete. The t-value of Training, Coaching, Tune up games and Competition is not significant having a p-value of greater than 0.05 level of significance.

This means that the behavior of the student-athlete to the sports activity was not influenced by physical activity, emotional activity, social behavior and psychological aspect 


\section{SJIF Impact Factor 2021: 8.013| ISI I.F.Value:1.241| Journal DOI: 10.36713/epra2016 ISSN: 2455-7838(Online) EPRA International Journal of Research and Development (IJRD) \\ Volume: 6 | Issue: 7 | July 2021 \\ - Peer Reviewed Journal}

\section{CONCLUSION}

Drawn the results of the study, the following results are set forth;

1. The null hypothesis stating that is no significant effect of the demographic profile of the student-athlete to the sports activity, is accepted, it can inferred that there is "no significant" effect between them.

2. The null hypothesis stating that the here is no significant effect of the behavior of the student-athlete to the sports activity" is accepted, it can inferred that there is "no significant" effect between them.

\section{RECOMMENDATION}

In the light of the findings and conclusion of the study, the following recommendations were drawn.

1. The student-athletes may advice to continue to enhance their ability to improved their performance to their respective chosen sports.

2. The Teacher-Coach may also maintain and improve their knowledge and abilities to continue to encourage the student-athletes to visualize the great opportunities in the near future the their respective sports.

3. The school administrator may implement the continuous communication and support to the student-athletes for them to be motivated and feel that they were being assisted even in the time of pandemic.

4. To the future researchers, a parallel study could be done in order to negate, confirm or improve the result of the present study.

\section{REFERENCES}

1. Ali, H.Y.; Danish, R.Q.; Asrar-ul-Haq, M. How corporate social responsibility boosts firm financial performance: The mediating role of corporate image and customer satisfaction. Corp. Soc. Responsib. Environ. Manag. 2020, 27, 166177.

2. Alvarez-Garcia, D.; Carlos Nunez, J.; Garcia, T.; Barreiro-Collazo, A. Individual, Family, and Community Predictors of Cyber-Aggression among Adolescents. Eur. J. Psychol. Appl. Leg. Context 2018, 10, 79-88.

3. Aquilina D. A study of the relationship between elite athletes' educational development and sporting performance. Int $J$ Hist Sport. 2013; 30:374-92.

4. Astuti, Tri M. P., et al. "The Socialization Model of National Character Education for Students in Elementary School Through Comic." Komunitas: International Journal of Indonesian Society and Culture, vol. 6, no. 2, Sep. 2014, pp. 260-270, doi:10.15294/komunitas.v6i2.3305.

5. Aylie, N. S., Mekonen, M. A., \& Mekuria, R. M. (2020).The Psychological Impacts of COVID-19 Pandemic Among University Students in Bench-Sheko Zone, South-west Ethiopia: A Community-based Cross-sectional Study Psychology Research and Behavior Management, Volume 13, 813-821. doi:10.2147/prbm.s275593

6. Babore, A.; Trumello, C.; Candelori, C.; Paciello, M.; Cerniglia, L. Depressive Symptoms, Self-Esteem and Perceived Parent-Child Relationship in Early Adolescence. Front. Psychol. 2016, 7, 982.

7. Bachmann C, Oesch P and Bachmann S (2018) Recommendations for improving adherence to home-based exercise: A systematic review. Physikalische Medizin, Rehabilitationsmedizin, Kurortmedizin 28(1): 20-31

8. Barbisch, D., Koenig, K. L., \& Shih, F. Y. (2015). Is there a case for quarantine? Perspectives from SARS to Ebola. Disaster Medicine and Public Health Preparedness, 9(5), 547-553. https://doi.org/ 10.1017/dmp.2015.38

9. Besi, M.; Sakellariou, M. Teachers'Views on the Participation of Parents in the Transition of their Children from Kindergarten to Primary School. Behav. Sci. 2019, 9, 124

10. Bento, G., \& Dias, G. (2017). The importance of outdoor play for young children's healthy development. Porto Biomedical Journal, 2(5), 157-160. doi:10.1016/j.pbj.2017.03.003

11. Breines, J. G., \& Chen, S. (2012). Self-compassion increases self-improvement motivation. Personality and Social Psychology Bulletin, 38, 1133-1143. https://doi.org/10.1177/0146167212445599

12. Catane, J. (2000). Conducting Research: A Practical Application. JMC Press Inc., 388 Quezon Avenue, Quezon City

13. Castro-Sánchez, M.; Zurita-Ortega, F.; Chacón-Cuberos, R.; López-Gutiérrez, C.J.; Zafra-Santos, E. Emotional intelligence, motivational climate and levels of anxiety in athletes from different categories of sports: Analysis through structural equations. Int. J. Environ. Res. Public Health 2018, 15, 894.

14. Centers for Disease Control and Prevention, March 12, 2020. Available: https://www.cdc.gov/coronavirus/2019nCoV/summary.html\#anchor_1580079137454

15. Cerniglia, L., Zoratto, F., Cimino, S., Laviola, G., Ammaniti, M., \& Adriani, W. (2017). Internet Addiction in adolescence: Neurobiological, psychosocial and clinical issues. Neuroscience \& Biobehavioral Reviews, 76, 174-184. https://doi.org/10.1016/j. neubiorev.2016.12.024. 


\section{SJIF Impact Factor 2021: 8.013| ISI I.F.Value:1.241| Journal DOI: 10.36713/epra2016 ISSN: 2455-7838(Online) EPRA International Journal of Research and Development (IJRD)

16. CDC. COVID-19: options to reduce quarantine for contacts of persons with SARS-CoV-2 infection using symptom monitoring and diagnostic testing. Atlanta, GA: US Department of Health and Human Services, CDC; 2020.. https://www.cdc.gov/coronavirus/2019-ncov/more/scientific-brief-options-to-reduce-quarantine.html

17. C. Gramaglia, A. Jona, F. Imperatori, E. Torre, P. Zeppegno, Cinema in the training of psychiatry residents: focus on helping relationships, BMC Med. Educ. 13 (1) (2013) 90.

18. Clemente-Suárez, V. J., Hormeño-Holgado, A., Jiménez, M., Benitez-Agudelo,J. C., Navarro-Jiménez, E.,PerezPalencia, $\quad$ N., et al. (2020). Dynamics ofpopulation immunity due to the herd effect in the COVID-19 pandemic.Vaccines 8:236. doi: 10.3390/vaccines8020236

19. Clemente-Suárez VJ, Fuentes-García JP, de la Vega Marcos R and Martínez Patiño MJ (2020) Modulators of the Personal and Professional Threat Perception of Olympic Athletes in the Actual COVID-19 Crisis. Front. Psychol. 11:1985.doi: 10.3389/fpsyg.2020.01985

20. China Daily. (2020a). Government works to increase access to medical supplies. https://www.chinadaily.com.cn/a/202002/10/WS5e409e95a310128217276212.h

21. China Daily. (2020b). Latest on the novel coronavirus outbreak. https://www.chinadaily.com.cn/al 202002/09/WS5e2a95d9a310128217273202.htm

22. Chınurum, J., OgunjImi, L. O., \& O'Neill, C. B. (2014). Gender and Sports in Contemporary Society. Journal of Educational and Social Research, 4(7), $25 . \quad$ Retrieved from http://www.richtmann.org/journal/index.php/jesr/article/view/5293

23. Commonwealth of Australia. National sport and active recreation policy framework. In. Canberra: Commonwealth of Australia; 2011.

24. Costa e Silva, L., Fragoso, M. I., \& Teles, J. (2017). Physical Activity-Related Injury Profile in Children and Adolescents According to Their Age, Maturation, and Level of Sports Participation. Sports Health: A Multidisciplinary Approach, 9(2), 118-125. doi:10.1177/1941738116686964

25. Cornwell, B., \& Laumann, E. O. (2015). The health benefits of network growth: New evidence from a national survey of older adults. Social Science \& Medicine (1982), 125, 94-106. https:// doi.org/10.1016/j.socscimed.2013.09.011

26. COVID-19 Working Group. (2020). Feasibility of controlling COVID-19 outbreaks by isolation of cases and contacts. The Lancet Global Health, 8(4), e488-e496. https://doi.org/10.1016/S2214-109X(20)30074-7

27. Crova, C., Struzzolino, I., Marchetti, R., Masci, I., Vannozzi, G., Forte, R., \& Pesce, C. (2014). Cognitively challenging physical activity benefits executive function in overweight children. Journal of Sports Sciences, 32, 201-211.

28. David Cenon, Patrick . Clamor, Wilfred Luis L,. Simpao Anne Claire S (2020). Time Allocation Before and During Enhanced Community Quarantine Among Students In A University In Manila, Philippines, https://pjhrd.upm.edu.ph/index.php/main/issue/view/27.

29. Delorme, N., Chalabaev, A., \& Raspaud, M. (2011). Relative age is associated with sport dropout: evidence from youth categories of French basketball. Scandinavian Journal of Medicine \& Science in Sports, 21(1), 120128. doi:10.1111/j.1600-0838.2009.01060.x

30. Donnelly, J. E., \& Lambourne, K. (2011). Classroom-based physical activity, cognition, and academic achievement. Preventive Medicine, 52, S36-S42. doi:10.1016/j.ypmed.2011.01.021

31. De Mooij, M. Consumer Behavior and Culture: Consequences for Global Marketing and Advertising; SAGE Publications Limited: London, UK, 2019.

32. Dent, A. L., \& Koenka, A. C. (2015). The relation between self-regulated learning and academic achievement across childhood and adolescence: A meta-analysis. Educational Psychology Review. Advance online publication. doi:10.1007/s10648- 015-9320-8

33. Eime, R. M., Harvey, J. T., Charity, M. J., Casey, M. M., Westerbeek, H., \& Payne, W. R. (2016). Age profiles of sport participants. BMC Sports Science, Medicine and Rehabilitation, 8(1). doi:10.1186/s13102-016-0031-3

34. Eime R, Sawyer N, Harvey J, Casey M, Westerbeek H, Payne W. Integrating public health and sport management: sport participation trends 2001-2010. Sport Manage Rev. 2015;18(2):207-17.

35. Eime R, Harvey J, Payne W. Dose-response of women's Health-Related Quality of Life (HRQoL) and life satisfaction to physical activity. J Phys Act Health. 2014;11:330-8.

36. Engebretsen L, Steffen K, Bahr R, Broderick C, Dvorak J, Janarv PM, Johnson A, Leglise M, Mamisch TC, McKay D, Micheli L, Schamasch P, Singh GD, Stafford DEJ, Steen H (2011) The International Olympic Committee consensus statement on age determination in high-level young athletes. Br J Sports Med 44:476-484

37. Ferguson, L. J., Kowalski, K. C., Mack, D. E., \& Sabiston, C. M. (2015). Self-compassion and eudaimonic well-being during emotionally difficult times in sport. Journal of Happiness Studies, 16, 12631280. https://doi.org/10.1007/s10902-014-9558-8

38. Foskett, R. L., and Longstaff, F. (2018). The mental health of elite athletes in theUnited Kingdom. J. Sci. Med. Sport 21, 765-770. doi: 10.1016/j.jsams.2017.11.016 


\section{SJIF Impact Factor 2021: 8.013| ISI I.F.Value:1.241| Journal DOI: 10.36713/epra2016 ISSN: 2455-7838(Online) EPRA International Journal of Research and Development (IJRD)

39. Fong, C. J., Davis, C. W., Kim, Y., Kim, Y. W., Marriott, L., \& Kim, S. (2016). Psychosocial Factors and Community College Student Success. Review of Educational Research, 87(2), 388-424. doi:10.3102/0034654316653479

40. Fong, C. J., Krause, J. M., Acee, T. A., \& Weinstein, C. E. (2015). The role of extrinsic motivation for Latino community college students: Differences between LEP (limited English proficient) and non-LEP students. Journal of Hispanic Higher Education. Advance online publication. doi:10.1177/1538192715607332

41. Gabbett, T.J.; Whyte, D.G.; Hartwig, T.B.; Wescombe, H.; Naughton, G.A. The relationship between workloads, physical performance, injury and illness in adolescent male football players. Sports Med. 2014, 44, 989-1003.

42. Gao, Z., Hannon, J. C., Newton, M., \& Huang, C. (2011). Effects of Curricular Activity on Students' Situational Motivation and Physical Activity Levels. Research Quarterly for Exercise and Sport, 82(3), 536544. doi:10.1080/02701367.2011.1059978

43. Ghazvini, S. D., \& Khajehpour, M. (2011). Gender differences in factors affecting academic performance of high school students. Procedia - Social and Behavioral Sciences, 15, 1040-1045. doi:10.1016/j.sbspro.2011.03.236

44. Giuliano, T.A.., Turner, K.L., Lundquist, J.C., and Knight, J.L. (2011).Gender and the Selection of Public Athletic Role Models. Journal of Sport Behavior, 30 (2), 161-199.

45. Giuliano, T.A.., Turner, K.L., Lundquist, J.C., and Knight, J.L. (2011).Gender and the Selection of Public Athletic Role Models. Journal of Sport Behavior, 30 (2), 161-199.

46. Green, C. S., Strobach, T., \& Schubert, T. (2014). On methodological standards in training and transfer experiments. Psychological Research, 78(6), 756-772. doi:10.1007/s00426-013-0535-3.

47. Gullu, S.; Yildiz, K. An Analysis on the Relationship among Trust in Manager, Political Behavior and Organizational Commitment: The Case of a Sports Organization. J. Educ. Train. Stud. 2019, 7, 116-127.

48. Haff, G. G., \& Nimphius, S. (2012). Training Principles for Power. Strength and Conditioning Journal, 34(6), 212. doi:10.1519/ssc.0b013e31826db467

49. Heath, G. W., Parra, D. C., Sarmiento, O. L., Andersen, L. B., Owen, N., Goenka, S., ... Brownson, R. C. (2012). Evidence-based intervention in physical activity: lessons from around the world. The Lancet, 380(9838), 272281. doi:10.1016/s0140-6736(12)60816-2

50. Hellewell, J., Abbott, S., Gimma, A., Bosse, N. I., Jarvis, C. I., Russell, T. W., Munday, J. D., Kucharski, A. J., Edmunds, W. J., Funk, S., \& Eggo, R. M, Centre for the Mathematical Modelling of Infectious Diseases

51. Honein MA, Christie A, Rose DA, Brooks JT, Meaney-Delman D, Cohn A, Sauber-Schatz EK, Walker A, McDonald LC, Liburd LC, Hall JE, Fry AM, Hall AJ, Gupta N, Kuhnert WL, Yoon PW, Gundlapalli AV, Beach MJ, Walke HT, CDC COVID-19 Response Team.MMWR Morb Mortal Wkly Rep. 2020 Dec 11; 69(49):1860-1867.

52. Ishihara, T., Sugasawa, S., Matsuda, Y., \& Mizuno, M. (2017). Relationship between sports experience and executive function in 6-12-year-old children: independence from physical fitness and moderation by gender. Developmental Science, 21(3), e12555. doi:10.1111/desc.12555

53. Inoue, Y.; Funk, D.C.; McDonald, H. Predicting behavioral loyalty through corporate social responsibility: The mediating role of involvement and commitment. J. Bus. Res. 2017, 75, 46-56.

54. Infratest dimap (2020) ARD DeutschlandTREND April 2020. Available at: www.infratest-dimap. de/umfragenanalysen/bundesweit/ard-deutschlandtrend/

55. Jayanthi NA, LaBella CR, Fischer D, Pasulka J, Dugas LR. Sports-specialized intensive training and the risk of injury in young athletes: a clinical case-control study. Am J Sports Med. 2015;43:794-801.

56. Jopp E, Schröder I, Maas R, Adam G, Püschel K (2011) Proximale Tibiaepiphyse im Magnetresonanztomogramm. Rechtsmed 20:464-468

57. Jones, V. F., \& Jones, L. S. (2012). Comprehensive classroom management, creating communities of support and solving problems (10th ed.). Upper Saddle River, NJ: Pearson.

58. Jowett, S., \& Shanmugam, V. (2016). Relational Coaching in Sport: Its psychological underpinnings and practical effectiveness. In R. Schinke, K.R. McGannon, \& B. Smith (Eds), Routledge International Handbook of Sport Psychology (pp. 471-484). Routledge

59. Juszkiewicz, J. (2015). Trends in community college enrollment and completion data, 2015. Washington, DC: American Association of Community Colleges.

60. Kadivar, M., Mafinejad, M. K., Bazzaz, J. T., Mirzazadeh, A., \& Jannat, Z. (2018). Cinemedicine: Using movies to improve students' understanding of psychosocial aspects of medicine. Annals of Medicine and Surgery, 28, 2327. doi:10.1016/j.amsu.2018.02.005

61. Kanematsu Y, Matsuura T, Kashiwaguchi S, Iwase T, Suzue N, Iwame T, Fukuta S, Hamada D, Goto T, Sairyo K (2015) Epidemiology of shoulder injuries in young baseball players and grading of radiologic findings of Little Leaguer's shoulder. J Med Invest, doi: 10.2152/jmi.62.123

62. Kandola, A., Lewis, G., Osborn, D. P. J., Stubbs, B., \& Hayes, J. F. (2020). Depressive symptoms and objectively measured physical activity and sedentary behaviour throughout adolescence: A prospective cohort study. The Lancet Psychiatry, 7(3), 262-271. https://doi.org/10.1016/S2215-0366(20)30034-1 


\section{SJIF Impact Factor 2021: 8.013| ISI I.F.Value:1.241| Journal DOI: 10.36713/epra2016 ～ISSN: 2455-7838(Online) EPRA International Journal of Research and Development (IJRD)

63. Keeler, L.A. (2012). Differences in Sport Aggression, Life Aggression, and Life Assertion Among Adult Male and Female Collision, Contact, and Non- Contact Sport Athletes. Journal of Sport Behavior, 30 (1), 57-77.

64. Killham, M. E., Mosewich, A. D., Mack, D. E., Gunnell,K. E., \& Ferguson, L. J. (2018). Women athletes' selfcompassion, self-criticism, and perceived sport performance. Sport, Exercise, and Performance Psychology, 7(3), 297307. http://dx.doi.org/10.1037/spy0000127

63. Klein, K.; Völckner, F.; Bruno, H.A.; Sattler, H.; Bruno, P. Brand Positioning Based on Brand Image-Country Image Fit. Mark. Sci. 2019, 38, 516-538.

64. Klostermann $C$ and Nagel S (2012) Changes in German sport participation: Historical trends in individual sports. International Review for the Sociology of Sport 49(5): 609-634.

65. Korpershoek, H., Harms, T., de Boer, H., van Kuijk, M., \& Doolaard, S. (2016). A Meta-Analysis of the Effects of Classroom Management Strategies and Classroom Management Programs on Students' Academic, Behavioral, Emotional, and Motivational Outcomes. Review of Educational Research, 86(3), 643680. doi:10.3102/0034654315626799

66. Kwon S, Janz KF, Letuchy EM, Burns TL, Levy SM. Active lifestyle in childhood and adolescence prevents obesity development in young adulthood. Obesity (Silver Spring) 2015;23:2462-9.

67. Laborde, S.; Guillén, F.; Mosley, E. Positive personality-trait-like individual differences in athletes from individualand team sports and in non-athletes. Psychol. Sport Exerc. 2016, 26, 9-13.

68. Lane, A.M., Beedie, C.J., Jones, M.V., Uphill, M., \& Devonport, T.J. (2012). The BASES expert statement on emotion regulation in sport. Journal of Sports Sciences, 30, 1189-1195. PubMed doi: 10.1080/02640414.2012.693621

69. Larkin, P., Mesagno, C., Spittle, M., \& Berry, J. (2015). International Journal of Sport Psychology, 46, 555-586.

70. Li, Y., \& Lerner, R. M. (2012). Interrelations of Behavioral, Emotional, and Cognitive School Engagement in High School Students. Journal of Youth and Adolescence, 42(1), 20-32. doi:10.1007/s10964-012-9857-5

71. Lupo C, Tessitore A, Capranica L, Rauter S, Doupona Topic M. Motivation for a dual-career: Italian and Slovenian student-athletes. Kin Si. 2012; 18:47-56.

72. Lupo, C., Mosso, C. O., Guidotti, F., Cugliari, G., Pizzigalli, L., \& Rainoldi, A. (2017). The Adapted Italian Version of the Baller Identity Measurement Scale to Evaluate the Student-Athletes' Identity in Relation to Gender, Age, Type of Sport, and Competition Level. PLOS ONE, 12(1), e0169278. doi:10.1371/journal.pone.0169278

73. McArdle WD, Katch FI, Katch VL. Exercise physiology : energy, nutrition, and human performance. 8th ed. Philadelphia: Lippincott Williams \& Wilkins; 2014.

74. MacFarlane, K., \& Woolfson, L. M. (2013). Teacher attitudes and behavior toward the inclusion of children with social, emotional and behavioral difficulties in mainstream schools: An application of the theory of planned behavior. Teaching and Teacher Education, 29, 46-52. doi:10.1016/j.tate.2012.08.006

75. McGuigan, M. R., Wright, G. A., \& Fleck, S. J. (2012). Strength Training for Athletes: Does It Really Help Sports Performance? International Journal of Sports Physiology and Performance, 7(1), 2-5. doi:10.1123/ijspp.7.1.2

76. Martinez-Escudero, J. A., Villarejo, S., Garcia, O. F., \& Garcia, F. (2020). Parental Socialization and Its Impact across the Lifespan. Behavioral Sciences, 10(6), 101. doi:10.3390/bs10060101

77. Martínez Cevallos, D., Alguacil, M., \& Calabuig Moreno, F. (2020). Influence of Brand Image of a Sports Event on the Recommendation of Its Participants. Sustainability, 12(12), 5040. doi:10.3390/su12125040

78. Martland R, Mondelli V, Gaughran F, et al. (2020) Can high-intensity interval training improve physical and mental health outcomes? A meta-review of 33 systematic reviews across the lifespan. Journal of Sports Sciences 38(4): 430469.

79. Maugeri, G.; Castrogiovanni, P.; Battaglia, G.; Pippi, R.; D’agata, V.; Palma, A.; Di Rosa, M.; Musumeci, G. The impact of physical activity on psychological health during Covid-19 pandemic in Italy. Heliyon 2020, 6, e04315

80. Morgan, S., \& McPherson, S. L. (2013). Developing tactics. In D. Farrow, J. Baker \& C. MacMahon (Eds.), Developing sport expertise (pp. 231-244). London andNewYork: Routledge

81. Mosewich, A. D., Crocker, P. R. E., \& Kowalski, K. C. (2014). Managing injury and other setbacks in sport: Experiences of (and resources for) high-performance women athletes. Qualitative Research in Sport, Exercise and Health, 6, 182-204. https://doi.org/10.1080/2159676X.2013.766810

82. Mujika, I.; Padilla, S. Detraining: Loss of training-induced physiological and performance adaptations. Part II. Sports Med. 2000, 30, 145-154.

83. Mutz, M., \& Gerke, M. (2020). Sport and exercise in times of self-quarantine: How Germans changed their behaviour at the beginning of the Covid-19 pandemic. International Review for the Sociology of Sport, 101269022093433. doi:10.1177/1012690220934335

84. Murayama, K., \& Elliot, A. J. (2012). The competition-performance relation: A meta-analytic review and test of the opposing processes model of competition and performance. Psychological Bulletin, 138(6), 10351070. https://doi.org/10.1037/a0028324 


\section{SJIF Impact Factor 2021: 8.013| ISI I.F.Value:1.241| Journal DOI: 10.36713/epra2016 ～ISSN: 2455-7838(Online) EPRA International Journal of Research and Development (IJRD)

85. NCCN. Survivorship version 2.2014. In: National Comprehensive Cancer Network Clinical Practice Guidelines in Oncology (NCCN Guidelines) 2014.

86. Niu C, Eng L, Qiu X, et al. Lifestyle behaviors in elderly cancer survivors: a comparison with middle-age cancer survivors. J Oncol Pract. 2015;11(4):e450-9.

87. O'Connor, D. B., Aggleton, J. P., Chakrabarti, B., Cooper, C. L., Creswell, C., Dunsmuir, S., et al. (2020). Research priorities for the COVID-19 pandemic and beyond: a call to action for psychological science. Br. J. Psychol. e12468

88. Oshimi, D.; Harada, M. Host residents' role in sporting events: The city image perspective. Sport Manag. Rev. 2019, 22, 263-275.

89. Palacios-Ceña D, Fernandez-de-Las-Peñas $C$, Hernández-Barrera V, JiménezGarcia R, Alonso-Blanco C, CarrascoGarrido P. Sports participation increased in Spain: a population-based time trend study of 21381 adults in the years 2000, 2005 and 2010. Br J Sports Med. 2012;46(16):1137-9.

90. Parra-Camacho, D.; Aguado-Berenguer, S.; Núñez-Pomar, J.M. Costs of holding a sporting event: The host community perception. J. Sports Econ. Manag. 2015, 5, 17-36

91. Paul, D. J., Gabbett, T. J., \& Nassis, G. P. (2015). Agility in Team Sports: Testing, Training and Factors Affecting Performance. Sports Medicine, 46(3), 421-442. doi:10.1007/s40279-015-0428-2

92. Pesce, C. (2012). Shifting the focus from quantitative to qualitative exercise characteristics in exercise and cognition research. Journal of Sport and Exercise Psychology, 34, 766-786.

93. Pietarinen, J., Soini, T., \& Pyhältö, K. (2014). Students' emotional and cognitive engagement as the determinants of well-being and achievement in school. International Journal of Educational Research, 67, 4051. doi:10.1016/j.ijer.2014.05.001

94. Pillay, L.; van Rensburg, D.C.C.J.; van Rensburg, A.J.; Ramagole, D.A.; Holtzhausen, L.; Dijkstra, H.P.; Cronje, T. Nowhere to hide: The significant impact of coronavirus disease 2019 (COVID-19) measures on elite and semi-elite South African athletes. J. Sci. Med. Sport 2020.

95. Prasetyo, Y. T., Castillo, A. M., Salonga, L. J., Sia, J. A., \& Seneta, J. A. (2020). Factors Affecting Perceived Effectiveness of COVID-19 Prevention Measures among Filipino during Enhanced Community Quarantine in Luzon, Philippines: Integrating Protection Motivation Theory and Extended Theory of Planned Behavior. International Journal of Infectious Diseases. doi:10.1016/j.ijid.2020.07.074

96. Reardon, C.L.; Hainline, B.; Aron, C.M.; Baron, D.; Baum, A.L.; Bindra, A.; Budgett, R.; Campriani, N.; CastaldelliMaia, J.M.; Currie, A. Mental health in elite athletes: International Olympic Committee consensus statement (2019). Br. J. Sports Med. 2019, 53, 667-699. [CrossRef] [PubMed]

97. Rice, J.A.; Hambrick, M.E.; Greenwell, T.C. Mass participant sport event brand associations: An analysis of two event categories. Int. J. Sport Manag. Mark. 2019, 19, 330-351

98. Rogers, L. Q., Carter, S. J., Williams, G., \& Courneya, K. S. (2018). Physical Activity. Handbook of Cancer Survivorship, 287-307. doi:10.1007/978-3-319-77432-9_15

99. Ruzek, E. A., Hafen, C. A., Allen, J. P., Gregory, A., Mikami, A. Y., \& Pianta, R. C. (2016). How teacher emotional support motivates students: The mediating roles of perceived peer relatedness, autonomy support, and competence. Learning and Instruction, 42, 95-103. doi:10.1016/j.learninstruc.2016.01.004

100. Santiago , Jomell M. , Cajucom Rita L. (2020) International Journal of Public Health Science (IJPHS) Vol. 9, No. 4, December 2020, Knowledge about COVID-19 among university students before the implementation of the enhanced community quarantine in Philippines. pp.321 328 ISSN: 2252-8806, DOI: 10.11591/ijphs.v9i4.20545

101. Schmalz, D. L., and Davison, K. K. (2012).Differences in Physical Self-concept Among Pre-Adolescents Who Participate in GenderTyped and Cross-Gendered Sports. Journal of Sport Behavior, 29 (4), 335-35

103. Schneider S, Yamamoto S, Weidmann C, Brühmann B. Sports injuries among adolescents: Incidence, causes and consequences. J Paediatr Child Health. 2012;48:183-189.

104. Sevilla, Consuelo G. et. al (2007). Research Methods. Rex Printing Company. Quezon City'

105. Sluis A, van der Elferink-Gemser MT, Coelho-e-Silva MJ, Nijboer JA, Brink MS, Visscher C. Sport injuries aligned to peak height velocity in talented pubertal soccer players. Int J Sports Med. 2014;35:351-355.

106. Sopa, I.S. \& Pomohaci, M. (2016). Tehnics of communication and social integration through sport. Lambert Academic Publishing. ISBN-13: 978-3-659-86350-9.

107. Sopa, I.S. \& Pomohaci M. (2015 a). Socialization through Sport, Effects of Team Sport on Students at Primary Level. Bologna: Medimond Publishing Company. ISBN: 978-88- 7587-718-7, p. 351.

108. Sopa, I.S. \& Pomohaci, M. (2015 b). Methodical discipline of Volleyball. Lambert Academic Publishing. ISBN-13: 978-3-659-78757-7.

109. Standage, M., Gillison, F. B., Ntoumanis, N., \& Treasure, D. C. (2012). Predicting Students' Physical Activity and Health-Related Well-Being: A Prospective Cross-Domain Investigation of Motivation across School Physical Education and Exercise Settings. Journal of Sport and Exercise Psychology, 34(1), 37-60. doi:10.1123/jsep.34.1.37 


\section{SJIF Impact Factor 2021: 8.013| ISI I.F.Value:1.241| Journal DOI: 10.36713/epra2016 ISSN: 2455-7838(Online) EPRA International Journal of Research and Development (IJRD)

110. Standage, M., \& Ryan, R.M. (2012). Self-determination theory and exercise motivation: Facilitating self-regulatory processes to support and maintain healthy and well-being. In G.C. Roberts \& D.C. Treasure (Eds.), Advances in motivation in sport and exercise (3rd ed., pp. 233-270). Champaign, IL: Human Kinetics.

111. Stracciolini A, Casciano R, Levey Friedman H, Meehan WP, Micheli LJ. Pediatric sports injuries: an age comparison of children versus adolescents. Am J Sports Med. 2013;41:1922-1929.

112. Strewe, C., Muckenthaler, F., Feuerecker, M., Yi, B., Rykova, M., Kaufmann, I.,et al. (2015). Functional changes in neutrophils and psychoneuroendocrineresponses during 105 days of confinement. J. Appl. Physiol. 118, 1122-1127. doi: 10.1152/japplphysiol.00755.2014

113. Studsrød, I., \& Bru, E. (2011). Perceptions of peers as socialization agents and adjustment in upper secondary school. Emotional and Behavioural Difficulties, 16(2), 159-172. doi:10.1080/13632752.2011.569401

114. Sutherland, L. M., Kowalski, K. C., Ferguson, L. J., Sabiston, C. M., Sedgwick, W. A., \& Crocker, P. R. E. (2014). Narratives of young women athletes' experiences of emotional pain and self-compassion. Qualitative Research in Sport, Exercise and Health, 6, 499-516. https://doi.org/10.1080/2159676X.2014.888587

115. Syväoja, H.J., Tammelin, T.H., Ahonen, T., Kankaanpää, A., \& Kantomaa, M.T. (2014). The associations of objectively measured physical activity and sedentary time with cognitive functions in school-aged children. PLoS ONE, 9, e103559.

116. Tang, F., Liang, J., Zhang, H., Kelifa, M. M., He, Q., \& Wang, P. (2020). COVID-19 related depression and anxiety among quarantined respondents. Psychology \& Health, 1-15. doi:10.1080/08870446.2020.1782410

117. Timme, M., Steinacker, J. M., \& Schmeling, A. (2016). Age estimation in competitive sports. International Journal of Legal Medicine, 131(1), 225-233. doi:10.1007/s00414-016-1456-7

118. Van de Grift, W., Van der Wal, M., \& Torenbeek, M. (2011). Ontwikkeling in de pedagogisch didactische vaardigheid van leraren in het basisonderwijs [Development in the pedagogical and didactic skills of primary school teachers]. Pedagogische Studiën, 88, 416-432.

119. Van Tuyckom C, Scheerder J, Bracke P. Gender and age inequalities in regular sports participation: a cross-national study of 25 European countries. J Sports Sci. 2011;28(10):1077-84

120. Vale, L.; Fernandes, T. Social media and sports: Driving fan engagement with football clubs on Facebook. J. Strateg. Mark. 2018, 26, 37-55

121. Varley MC, Gabbett T, Aughey RJ. Activity profiles of professional soccer, rugby league and Australian football match play. J Sports Sci. 2014;32(20):1858-66.

122. Vaughan RS, Edwards EJ and MacIntyre TE (2020) Mental Health Measurement in a Post Covid-19 World: Psychometric Properties and Invariance of the DASS-21 in Athletes and Non-athletes. Front. Psychol. 11:590559. doi: 10.3389/fpsyg.2020.590559

123. Wachsmuth, S., Jowett, S., \& Harwood, C. (2017). Conflict among athletes and their coaches: what is the theory and research so far? International Review of Sport and Exercise Psychology, 10 (1), 84-107.

124. Wagstaff, C. R. D. (2014). Emotion Regulation and Sport Performance. Journal of Sport and Exercise Psychology, 36(4), 401-412. doi:10.1123/jsep.2013-0257

125. Wang, C.; Pan, R.; Wan, X.; Tan, Y.; Xu, L.; Ho, C.S.; Ho, R.C. Immediate psychological responses and associated factors during the initial stage of the 2019 coronavirus disease (COVID-19) epidemic among the general population in China. Int. J. Environ. Res. Public Health 2020, 17, 1729

126. Wang, C. W., Ho, R. T., Chan, C. L., \& Tse, S. (2015). Exploring personality characteristics of Chinese adolescents with internet-related addictive behaviors: Trait differences for gaming addiction and social networking addiction. Addictive Behaviors, 42, 32-35. https://doi.org/10.1016/j.addbeh.2014.10.039

127. Wang, M., \& Eccles, J. (2013). School context, achievement motivation, and academic engagement: A longitudinal study of school engagement using a multidimensional perspective. Learning and Instruction, 28, 12-23.

128. Wang, R., Chen, Z., Zhou, Y., Shen, L., Zhang, Z., \& Wu, X. (2019). Melancholy or mahjong? Diversity, frequency, type, and rural-urban divide of social participation and depression in middle-and old-aged Chinese: A fixed-effects analysis. Social Science \& Medicine (1982)), 238, 112518https://doi.org/10.1016/j.socscimed.2019.112518

129. Warburton, D. E. R., \& Bredin, S. S. D. (2016). Reflections on Physical Activity and Health: What Should We Recommend? Canadian Journal of Cardiology, 32(4), 495-504. doi:10.1016/j.cjca.2016.01.024

130. Wartberg, L., Kriston, L., \& Thomasius, R. (2019). Internet gaming disorder and problematic social media use in a representative sample of German adolescents: prevalence estimates, comorbid depressive symptoms and related psychosocial aspects. Computers in Human Behavior. doi:10.1016/j.chb.2019.09.014

131. Wartberg, L., Kriston, L., Bröning, S., Kegel, K., \& Thomasius, R. (2017). Adolescent problematic Internet use: Is a parental rating suitable to estimate prevalence and identify familial correlates? Computers in Human Behavior, 67, 233-239. https://doi. org/10.1016/j.chb.2016.10.029.

132. Wentzel, K. R. (2015). Socialization in school settings. In J. E. Grusec \& P. D. Hastings (Eds.), Handbook of socialization: Theory and research (p. 251-275). The Guilford Press. 
SJIF Impact Factor 2021: 8.013| ISI I.F.Value:1.241| Journal DOI: 10.36713/epra2016

ISSN: 2455-7838(Online)

EPRA International Journal of Research and Development (IJRD)

Volume: 6 | Issue: 7 | July 2021

- Peer Reviewed Journal

133. Weissberg, R. P., Durlak, J. A., Domitrovich, C. E., \& Gullotta, T. P. (Eds.). (2015). Social and emotional learning: Past, present, and future. In J. A. Durlak, C. E. Domitrovich, R. P. Weissberg, \& T. P. Gullotta (Eds.), Handbook of social and emotional learning: Research and practice (p. 3-19). The Guilford Press.

134. Wicker P, Hallmann $K$ and Breuer C (2013) Analyzing the impact of sport infrastructure on sport participation using geo-coded data: Evidence from multi-level model. Sport Management Review 16(1): 54-67.

135. World Health Organization. (2020). Statement on the second meeting of the International Health Regulations (2005) Emergency Committee regarding the outbreak of novel coronavirus (2019- nCoV). https://www.who.int/newsroom/detail/30-01-2020-statement-on-the-second-meetingof-the-international-health-regulations-(2005)-emergencycommittee-regarding-the-outbreak-ofnovel-coronavirus-(2019-ncov)

136. Young WB, Dawson B, Henry GJ. Agility and change of direction speed are independent skills; implications for training for agility in invasion sports. Int J Sports Sci Coach. 2015;10(1):159-69.

137. Z. Klemenc Ketiš, I. Švab, Using movies in family medicine teaching: a reference to EURACT Educational Agenda, Slovenian J. Public Health 56 (2) (2017) 99-106.

138. Zentgraf, K., Heppe, H., \& Fleddermann, M.-T. (2017). Training in interactive sports. German Journal of Exercise and Sport Research, 47(1), 2-14. doi:10.1007/s12662-017-0441-8 